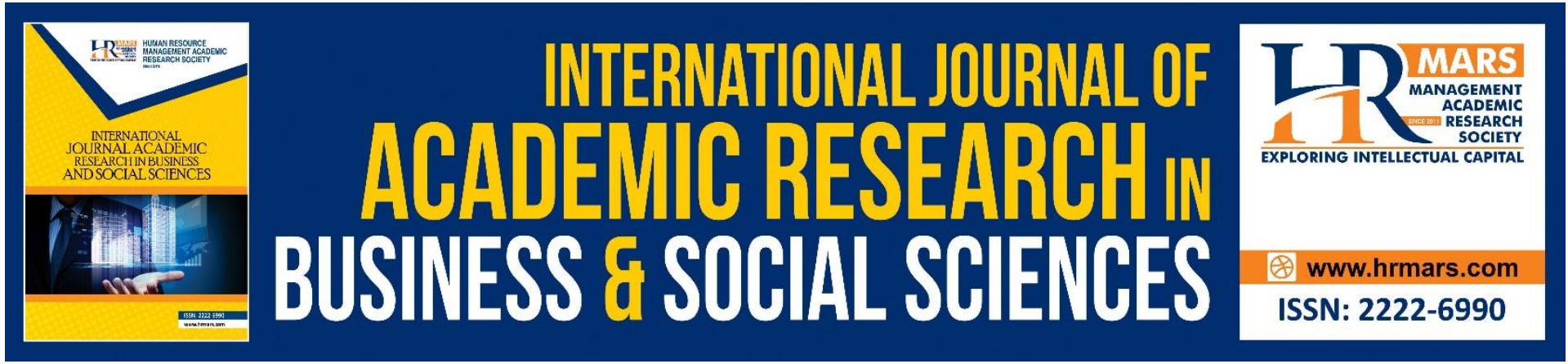

\title{
Effects of the Mining Legal Framework on Women Participation in Artisanal and Small Scale Mining: Lessons from Taita Taveta County (Kenya)
}

\author{
David Mugo, Florence Ondieki-Mwaura, Miriam Omolo
}

To Link this Article: http://dx.doi.org/10.6007/IJARBSS/v11-i7/9969

DOI:10.6007/IJARBSS/v11-i7/9969

Received: 10 May 2021, Revised: 12 June 2021, Accepted: 25 June 2021

Published Online: 07 July 2021

In-Text Citation: (Mugo et al., 2021)

To Cite this Article: Mugo, D., Ondieki-Mwaura, F., \& Omolo, M. (2021). Effects of the mining legal framework on women participation in Artisanal and Small Scale Mining: Lessons from Taita Taveta County (Kenya). International Journal of Academic Research in Business and Social Sciences, 11(7), 125-138.

Copyright: (c) 2021 The Author(s)

Published by Human Resource Management Academic Research Society (www.hrmars.com)

This article is published under the Creative Commons Attribution (CC BY 4.0) license. Anyone may reproduce, distribute, translate and create derivative works of this article (for both commercial and non-commercial purposes), subject to full attribution to the original publication and authors. The full terms of this license may be seen at: http://creativecommons.org/licences/by/4.0/legalcode

Vol. 11, No. 7, 2021, Pg. 125 - 138

Full Terms \& Conditions of access and use can be found at http://hrmars.com/index.php/pages/detail/publication-ethics 


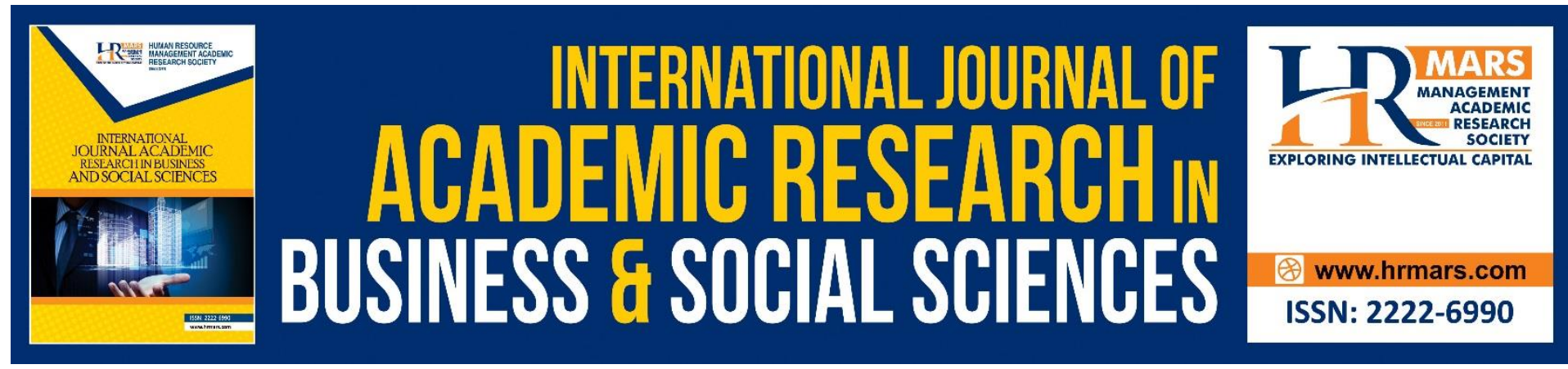

\title{
Effects of the Mining Legal Framework on Women Participation in Artisanal and Small Scale Mining: Lessons from Taita Taveta County (Kenya)
}

\author{
${ }^{1}$ David Mugo, ${ }^{2}$ Florence Ondieki-Mwaura PhD, ${ }^{3}$ Miriam Omolo \\ $\mathrm{PhD}$ \\ ${ }^{1} \mathrm{PhD}$ Candidate, Department of Development Studies, School of Communication and \\ Development Studies, Jomo Kenyatta University of Agriculture and Technology (JKUAT), \\ ${ }^{2}$ Senior Lecturer, Department of Development Studies, School of Communication and \\ Development Studies Jomo Kenyatta University of Agriculture and Technology (JKUAT), \\ ${ }^{3}$ Director, African Policy Research Institute, (APRI) \\ Email: thiongomugo@gmail.com,fnmwaura@ihrd.jkuat.ac.ke,miriamomolo@yahoo.com
}

\begin{abstract}
Artisanal and small-scale mining (ASM) is increasingly the focus of the national efforts to effectively regulate the sector as an initiative to ameliorate national benefits by increasing women participation in the sector while seeking to address challenges that they face. Despite women's participation in the ASM sector being estimated at nearly $50 \%$ in the mining areas, their significant participation has largely been overlooked. The study investigated the effect of legal framework on women participation in ASM. To achieve this, the study used data from a cross-sectional survey of 146 women working at different nodes of the ASM sector in Taita Taveta County. Descriptive statistics and linear regression was employed to analyse data. The results show that the requirements for mining permits have a positive effect on women participation in ASM while the process of obtaining a mining license had a negative influence. We recommend policy frameworks that facilitate easy access to mining licenses by women in the ASM sector. Specifically, there is a need to establish a field office for offering the ASM mining licenses and reduce bureaucracies associated with obtaining mining permits.
\end{abstract}

Keywords: Artisanal and Small-Scale Mining, Women Participation, Policy, Legal Framework

\section{Introduction}

Artisanal and small-scale mining (ASM) has in recent times experienced monumental growth worldwide, particularly in rural areas of the developing countries where unemployment rates are relatively higher and widespread. There are currently more than 190.5 million people that are either directly or indirectly involved in the ASM sector with women making a significant number of these participants (IGF, 2017). Despite the critical dearth of data, women have been estimated to account for $30 \%$ of the global ASM workforce and up to $50 \%$ in Africa. Albeit, the substantive figure of women in the sector, there is an alarming lack of recognition in nearly all the spheres from development programs, mining communities, public and private sectors, academia, and even the legal framework. In spite of the inadequate recognition, the 
sector has continued to experience rapid expansion fueled by the contemporary surge in the market prices for precious metals and stones. As a result, ASM has also been categorized as a typical informal sector especially in third world countries due to its significance in the labour market with cardinal contributions to the generation and production of rural income, hence a survival route for thousands of rural households (ILO, 2018). Because of this, many people in the mining region like Taita Taveta (Kenya) have joined the sector. Statistics indicate that more than $50 \%$ of the labour force in the region are women. Though there is a high level of women participation in the ASM, they continuously face exclusion in critical aspects, conspicuously land access and ownership, policy and decision making, leadership, and mineral rights (Ayuk et al., 2019).

The emergence of the ASM sector in Kenya presents an opportunity for development in the country. The sector offers an opportunity to potentially transform the economy through employment and income generation especially to those in the lower-income group and hence, poverty alleviation. There is significant involvement and input of women to the artisanal and small-scale mining sector (Hinton et al., 2003). Women play a much more substantial role in artisanal and small-scale mining as workers or providers of support roles (e.g., as chefs and service providers). However, a growing body of evidence reveals that women have not fully benefited from the ASM since they mainly operate at the lower level of the value chain, with dismal returns or benefits (Maclin et al., 2017). In addition, women have minimal participation in decision making in the sector (Yakovleva, 2007).

Auxiliary obstructions reduce women's capacity to completely take an interest in and advantage in ASM (Buxton, 2013). The obstructions include a myriad of social-cultural taboos that keep women from entering mine locales or taking part in some roles, and women's domestic chores such as cooking, gathering water, and taking care of families. In some countries, a woman is not allowed to work underground or get inside a mine site if menstruating (Mkubukeli and Tengeh, 2016). Lack of proper legislation and the legal system keeps women from controlling their proceeds from ASM activities; the area is unregulated and subsequently connected with corruption, complicated bureaucracy, and misuse by middlemen (brokers). Women are also constrained from access to assets such as land, and the male head household often controls the family finances and financial credit (Siwale and Siwale, 2017).

The majority of women in Taita Taveta County live in the countryside and are mainly engaged in subsistence farming (Government of Kenya, 2015). According to the Kenya National Bureau of Statistics (KNBS, 2017), the county is ranked $28^{\text {th }}$ among the poorest counties in Kenya with a poverty rate of $54.0 \%$, which is extremely higher than the national average of $36.1 \%$. With the emergence of ASM, most women have switched from agricultural lands to ASM for job opportunities, livelihood and economic opportunities (Mpagi 2017). Given the important role of women's involvement in economic activities through the provision of labour, ownership of production inputs, direct participation in the production process, and carrying out the household chores (Mwakumanya et al., 2016), there is a need to understand the local gender dynamics, detachments and encounters around the ASM sector. This calls for stakeholders to recognize the gender dynamics at all stages of the ASM value chain before developing ASM assistance strategies and/or programmes, and the need to mainstream gender in the artisanal and small-scale mining sector (Rijksoverheid, 2015). This would go a long way in providing opportunities for viable employment among women in rural areas, which in turn would significantly reduce the levels of rural poverty by involving women in development (Yakovleva, 2007). 
From existing literature, the role of women in ASM and towards economic empowerment, and the extent of women participation in the sector is very clear. A few studies in Kenya, Tanzania and the Democratic Republic of Congo (DRC) have linked cultural practices, insufficient capital and legal framework as key impediments to women participation in the ASM sector. However, many of these studies are based on desktop review and not empirical findings. In addition, these studies have paid limited focus legal framework aspects such artisanal mining permit requirements, and the process for which the current study has examined. Furthermore, the majority of the previous studies have relied more on descriptive studies, but the current study adopted both descriptive and regression analysis, which is the most reliable method of identifying what factors have a great effect, the nature of the effect (negative or positive) or what factors matter most to help in drawing conclusions. Moreover, most studies have focused on the socioeconomic and not legal framework. Thus, the study investigated the effect of mining legal framework on on women participation in the artisanal and small-scale mining value chain. Specifically, the study sought:

- To determine the effect of artisanal mining permit requirements on women participation in the artisanal and small-scale mining value chain and;

- To examine how fees and taxes that women are required to pay in ASM affect their participation in the mining value chain.

Findings of the study will directly inform the successful design and implementation of ASM assistance policies and programmes that could bridge the gap in the attainment of $10 \%$ contribution of GDP by the extractive sector by the year 2030 as set out in the Kenya Vision 2030, the national development blueprint.

\section{Literature}

In the mining sector, there is a structure of inequalities and discrimination in access to resources, skills and the market which impact negatively women more than men. The Gender and Development (GAD) notion views women as mediators of change rather than as passive receivers of progress efforts (Sadan, 2004). In this case, women are not supposed to engage only in manual jobs in mining such as cleaning the whole value chain instead. One of the approaches recommended by the GAD approach is the self-organization of women at the local, regional and national levels. Women in mining associations help women to advocate for issues that concern them and government can adopt and enforce equal opportunity laws in artisanal mining. The GAD concept advised on an institutional change within socioeconomic and political structures to eliminate the gender variations and strengthens the position of women.

Empirical studies argue that strategies that limit or prevent women from gaining concessions or land rights contribute to the feminization of poverty (World Bank, 2000). In Kenya, female miners can have access to land but cannot control land and mining activities as well (Mishra, \& Reddy, 2012). The majority of women in mining in Kenya like any other African countries are in the informal artisanal mining sector, which has little regulation and is often dominated by men (Hirons, 2020). While small-scale mining has been legalised in Kenya, detailed rules are needed to guide the operationalization and engendering of this provision(Analysis of the Mining ACT, 2016).

Fearon and Agbah (2015) studied the perceptions of female taking part in artisanal and smallscale mining: A case study of Birim North District of Ghana. The study purposed to study the causes of female involvement in the ASM sector and the influence of this type of employment on women's income, health and families. The findings of the study exhibit the utility of sexual 
orientation mainstreaming in the small scale mining formalization process, and in addition, they need to advance other practical business openings to serve women who live in the country regions. To ensure artisanal mining becomes a sustainable economic opportunity for both men and women, there is an urgent need to formalize small-scale mining operations (Zollo, 2019). Hirons (2020) in a study, local perspectives on the artisanal and small-scale mining in the Madre de Dios gold fields, Peru noted that formalization is not only about the control and mitigation of the adverse impacts of ASM but also about harnessing the helpful participation and channelling benefit flow toward politically chosen directions. The article emphasised the need for the government to formalising artisanal mining operations; supporting women artisanal miners with training and technical expertise and engendering policies and development plans involving women artisanal miners.

Hinton et al (2003) in the study, women and Artisanal Mining: Gender Roles and the Road Ahead noticed that context of women and artisanal mining, key administration issues relating to the adequacy of approach in propelling correspondence, especially as far as land rights, a portrayal of women in basic leadership forms, and an institutional situation that is helpful for investment by women. In a few nations, women may have legitimate access to land and other capital resources. These hindrances on women' territory rights prevent their capacity to get to different assets and to utilize the property as security to get credits, women experience issues embracing elective advances and enlisting work when required (Mkubukeli \&Tengeh, 2016).

\section{Legal and Regulatory Framework in Artisanal and Small-scale mining}

The legal and regulation frame worked have been operationally defined as procedure or requirement for artisanal miners' operations. This includes artisanal miners permit requirements for ASM miners/groups, affordability of Fees that women ASM required to pay and availability of environmental Permit (NEMA). The fees or amount of payable tax to business whether paid either annually or periodically to either County or National Government, the technical or administrative support provided by County and National Government officers to artisanal miners and finally identify how women are involved in decision-making processes in mining issues.

\begin{tabular}{|l|}
\hline $\begin{array}{l}\text { Artisanal Miners permit requirements for } \\
\text { ASM miners/group }\end{array}$ \\
\begin{tabular}{|l|c|}
\hline $\begin{array}{l}\text { Fees and taxes that women ASM required } \\
\text { to pay in artisanal and Small-scale } \\
\text { Environment /Health requirement on } \\
\text { women in artisanal and small-scale mining }\end{array}$ \\
Contribution of ASM in \\
\hline
\end{tabular} \mid $\begin{array}{c}\text { Womining effective } \\
\text { participation in artisanal }\end{array}$ \\
\hline
\end{tabular}

Figure 1: Conceptual framework 


\section{Research Methodology}

The sampling frame was generated from the list of all women artisanal miners in Taita Taveta County. The choice of the 16 women mining groups was informed by the County ASM registry. The study involved women who had been in operation for more than three years. The list was filtered to include women with consistent membership. Stratified sampling was used to get the sample from the four sub-counties of Taita Taveta County. A sample size of 230 women artisanal miners were systematically selected following Mugenda and Mugenda (2003) formula as presented in equation 1.

$n=\frac{N}{1+n(e)^{2}}$ equation 1

Where $\mathrm{n}$ is the sample size, $\mathrm{N}$ is the population size, and e is the level of precision. When this formula is applied to the sample, the following sample is obtained.

Therefore;

$\frac{230}{1+230(.05)^{2}}=126$ women equation 2

Primary data was collected through semi-structured questionnaires. This process involved administering the questionnaires to the respondents with help of research assistants. This enabled a similar understanding of the questions by all respondents thus minimizing misinterpretation of concepts by different respondents. Questionnaires are used frequently in educational research to measure attitudes, beliefs, opinions, and other types of information. Information about a population can be inferred from the study participants' survey responses, also known as the sample (Rowley, 2014). According to Zohrabi (2013), questionnaires allow respondents to analyze their answers without an interviewer's intervention carefully. Semi-structured questionnaires were used to collect data from professionals in mining matters at both the national and county government this includes County Executive committee for mining, Director mining and field mining officer. Both quantitative and qualitative data analysis approaches were used. Before analysis, raw data from questionnaires were checked for completeness and coded for analysis. Data were analysed using Statistical Package for Social Sciences (SPSS). Percentages and mean were used to define the set of data by identifying the central position within that set of data. A chi-square test for independence was used to compare if two variables in a contingency table are related. Finally, simple regression analysis was applied to help us comprehend which amongst the independent variables are connected to the dependent variable and to further explore the forms of these relations between a dependent variable and independent variables (Liu et al., 2020). The following equation was estimated:

$\hat{Y}=b_{0}+b_{1} X_{1}+b_{2} X_{2} \ldots+b_{p} X_{P}$ equation 3

where $\hat{Y}$ is the predicted or expected value of the dependent variable (women participation) $X_{1}$ through $X_{P}$ are $p$ distinct independent or predictor variables (understanding of mining laws, mining permit requirements, and process of obtaining mining permits).

\section{Results and Discussion}

The study collected data from 146 women who participated in ASM within Taita Taveta County. This was more than a $100 \%$ response rate. This higher rate of return was attributed to the fact that the researcher adopted interviewer administration of the questionnaire. According to the results, 44 per cent of the respondents were from Mwatate Sub-County, 32 per cent from Voi Sub-County, 12 per cent from Taveta, and 12 per cent from Wundanyi SubCounty.

Next, Table 1 presents the demographic characteristics of the women. 
Table 1: Demographic Characteristics of the Respondents ( $N=146)$

\begin{tabular}{lllll}
\hline Characteristic & Min. & Max. & Mean & Std. Deviation \\
\hline Age of respondents (years) & 20.00 & 67.00 & 40.12 & 8.66 \\
Years of mining & 0.50 & 28.00 & 8.06 & 5.47 \\
Distance between home and the mine $(\mathrm{km})$ & 0.20 & 39.00 & 12.93 & 8.03 \\
\hline
\end{tabular}

Source: Author (2020)

The results reveal that the average age of the women who participated in ASM is 40.12 years with a minimum of 20 and a maximum of 67 years at the time of this study. This implies that the young, as well as the elderly women, participate in ASM. In addition, these findings mean that age is not a barrier to participation in ASM. Regarding the number of years, they had spent in ASM, the study has established the average age of 8.06 years with a minimum of 0.5 years and a maximum of 28 years. This suggests that most of them were more experienced in ASM activities and, therefore, were competent enough to participate in the study. In terms of distance, the respondents had to cover an average of $12.93 \mathrm{~km}$ from their homes to the nearest ASM industries per trip with a minimum of $0.2 \mathrm{~km}$ and a maximum of $39 \mathrm{~km}$. This implies that most women travel a long distance to get to the mining site, an indication of the struggles they undergo to earn a living

Legal Framework and Effect on Women Participation in ASM

The study sought to investigate the effect of mining legal framework on women participation in artisanal and small-scale mining. The respondents were asked for their opinion on several issues regarding mining legal and regulatory framework. The majority of respondents said that the process of acquiring ASM permits is complicated and time-wasting and they were therefore forced to corrupt mining officers in some cases to get the permits. This was also fueled by the fact that distance to the mining office was located at Voi Sub-county, which was far from the mining camps. There was also a lack of awareness, education and clear guidelines for easy application of ASM permits.

Qualitative findings show that most women miners declined to apply for ASM permits in fear of government compulsory taxation even when there are no mines. In addition, a few women who work as traders, sell their final products to non-licensed traders (brokers) who, in most cases, exploit them by offering lower prices (see Table 2). For instance, findings indicate that 43 women sold Yellow Stone to unlicensed buyers against 5 who reported having sold to licensed buyers. Similar findings are reported for sand, but, for the main mineral (Gamestone), the majority of the respondents (30) sold to licensed buyers.

Table 2: Cross Tabulation between commodity mined and the market (buyers)

\begin{tabular}{|c|c|c|c|c|c|c|c|}
\hline & & $\begin{array}{l}\text { Yellow } \\
\text { Stone }\end{array}$ & $\begin{array}{l}\text { Gamestone } \\
\text { (Green Garment) }\end{array}$ & Road-lite & Sand & Mica & Total \\
\hline Where the & Licensed buyer & 5 & 30 & 0 & 0 & 0 & 35 \\
\hline $\begin{array}{l}\text { Contact } \\
\text { sells their }\end{array}$ & $\begin{array}{l}\text { Unlicensed } \\
\text { buyer }\end{array}$ & 43 & 7 & 1 & 14 & 4 & 69 \\
\hline products & Other & 2 & 20 & 0 & 0 & 0 & 22 \\
\hline Total & & 50 & 57 & 1 & 14 & 4 & 126 \\
\hline
\end{tabular}

Source: Author (2020) 
Generally, these findings point to the challenges women go through when marketing their mines, as the unlicensed buyers could be the source of their exploitation in terms of income. Studies show that obtaining a license involves significant costs and bureaucratic barriers (Werthmann, 2009). The ability to obtain an ASM license is based on awareness of procedures, financial and technical capacity, and personal freedom to get a license, requirements that are of great challenge to female miners (Yakovleva, 2007).

Table 3 presents summary findings on the women's understanding of the mining regulations. The findings indicate that majority of the respondents (62.1 per cent) indicated that they did not understand the laws that affect rights to access mineral deposits. In addition, 61.1 per cent reported that the mining laws should be changed, 64.6 per cent were not aware of the environmental effects of ASM on women, 97.9 per cent said there were no enough women in government structures that influence ASM, 96.9 per cent reported that mining administration offices are far away, 51.3 per cent of the respondents indicated that there was ease to comply with the laws whilst only 38.5 per cent expressed comfort in dealing with law enforcement agents.

Table 3: Respondents' opinion on mining regulatory aspects

\begin{tabular}{lll}
\hline & Yes & No \\
\hline $\begin{array}{l}\text { I understand the laws that affect rights to access } \\
\text { mineral deposits }\end{array}$ & 37.9 & 62.1 \\
$\begin{array}{l}\text { Should the laws be changed } \\
\begin{array}{l}\text { Are there enough women in government } \\
\text { structures that influence ASM }\end{array}\end{array}$ & 61.1 & 38.9 \\
$\begin{array}{l}\text { Are mining administration offices close enough } \\
\text { Ease of complying with the laws }\end{array}$ & 3.1 & 97.9 \\
Comfort in dealing with law enforcement agents & 38.5 & 96.9 \\
\hline
\end{tabular}

Source: Author (2020)

Next, the study sought to establish whether the respondents had mining permits. The majority of the women (65 per cent) did not have valid mining permits. When asked for the reasons why they did not have valid licenses, they cited various reasons as illustrated in Figure 2. 


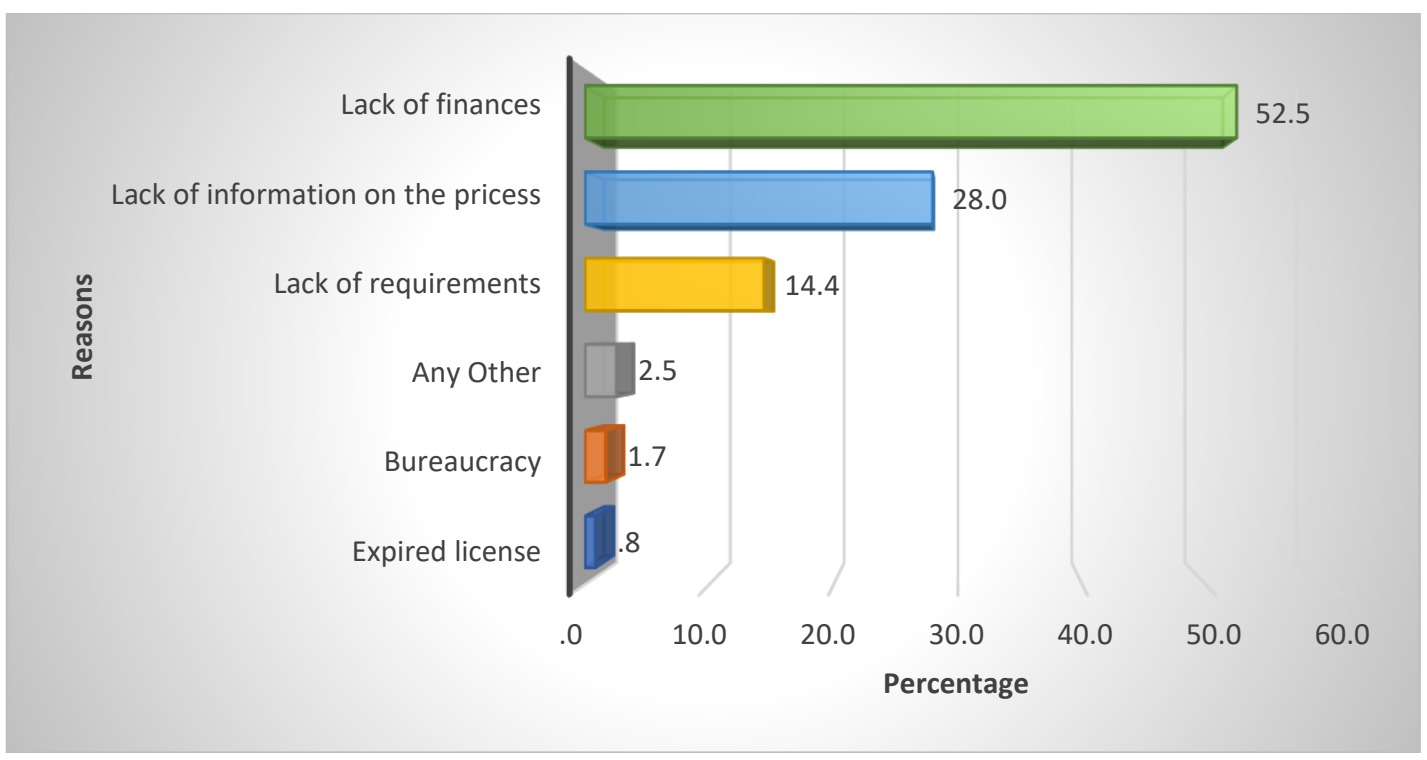

Figure 2 Reasons for not having a mining license

Source: Author (2020)

Most of the respondents cited challenges such as lack of finances ( 52.5 per cent), while others lacked mining permits due to lack of information on the prices and where to acquire the mining permit (28 per cent), lack of necessary documentation to get a mining permit (14.4 per cent), bureaucracy (1.7 per cent) and expired licenses (1 per cent). This result suggests that only 35 per cent of the respondents were authorized to work in the ASM miners.

Having presented and discussed descriptive statistics on mining legal framework and its relationship with women participation in ASM, the next sub-section discussed correlation, regression and hypothesis test regarding the second objective.

4.1.1 Correlation analysis

Table 4 presents a correlation between mining legal framework and women participation in ASM. 
Table 4: Correlation between mining legal framework and women participation in ASM

\begin{tabular}{|c|c|c|c|c|c|}
\hline & & $\begin{array}{l}\text { Women } \\
\text { participati } \\
\text { on in ASM }\end{array}$ & $\begin{array}{l}\text { Understandin } \\
\mathrm{g} \text { of mining } \\
\text { laws }\end{array}$ & $\begin{array}{l}\text { Mining } \\
\text { permit } \\
\text { requiremen } \\
\text { ts }\end{array}$ & $\begin{array}{l}\text { Process of } \\
\text { obtaining } \\
\text { mining permits }\end{array}$ \\
\hline \multirow{4}{*}{$\begin{array}{l}\text { Women } \\
\text { participation } \\
\text { ASM }\end{array}$} & Pearson & 1 & $.219^{* *}$ & $.343^{* *}$ & $.288^{* *}$ \\
\hline & Correlation & & & & \\
\hline & Sig. (2-tailed) & & .003 & .000 & .000 \\
\hline & $\mathrm{N}$ & 183 & 183 & 183 & 183 \\
\hline \multirow{3}{*}{$\begin{array}{l}\text { Understanding of } \\
\text { laws of mineral } \\
\text { deposits }\end{array}$} & Pearson & $.219^{* *}$ & 1 & $.382^{* *}$ & $.533^{* *}$ \\
\hline & Sig. (2-tailed) & .003 & & .000 & .000 \\
\hline & $\mathrm{N}$ & 183 & 195 & 195 & 195 \\
\hline \multirow{4}{*}{$\begin{array}{l}\text { Mining permit } \\
\text { requirements }\end{array}$} & Pearson & $.343^{* *}$ & $.382^{* *}$ & 1 & $.665^{* *}$ \\
\hline & Correlation & & & & \\
\hline & Sig. (2-tailed) & .000 & .000 & & .000 \\
\hline & $\mathrm{N}$ & 183 & 195 & 195 & 195 \\
\hline \multirow{3}{*}{$\begin{array}{l}\text { Process of } \\
\text { obtaining mining } \\
\text { permits }\end{array}$} & $\begin{array}{l}\text { Pearson } \\
\text { Correlation }\end{array}$ & $.288^{* *}$ & $.533^{* *}$ & $.665^{* *}$ & 1 \\
\hline & Sig. (2-tailed) & .000 & .000 & .000 & \\
\hline & $\mathrm{N}$ & 183 & 195 & 195 & 195 \\
\hline
\end{tabular}

The correlation statistics revealed a positive correlation between women participation in ASM and all the variables of the legal framework, which include understanding of mining laws, mining permit requirements and the process of obtaining a permit. This is because all the coefficients are positive and statistically significant given $p$-values of less than 0.05 . This implies that there is at least a relationship between women participation in ASM and the mining legal framework. The next sub-section presents regression analysis results.

\section{Regression for Legal Framework and Women Participation in ASM}

OLS regression was carried out to determine the influence of awareness and adherence to the laws about mining on women participation in mining. The dependent variable was participation in mining measured by the number of hours' women participate in mining activities. The regression was analysed at a confidence level of 95 per cent. The summary results are presented in Table 5. 
Table 5: OLS Estimated results

\begin{tabular}{|c|c|c|c|c|c|}
\hline $\begin{array}{l}\text { Independent } \\
\text { variables }\end{array}$ & B & Std. Error & Beta & $\mathbf{T}$ & Sig. \\
\hline (Constant) & 5.431 & .627 & & 8.664 & .000 \\
\hline $\begin{array}{l}\text { Understandi } \\
\text { ng of mining } \\
\text { laws }\end{array}$ & .395 & .369 & .087 & 1.071 & .286 \\
\hline $\begin{array}{l}\text { Mining } \\
\text { permit } \\
\text { requirement } \\
\mathrm{s}\end{array}$ & 1.165 & .405 & .265 & 2.878 & .004 \\
\hline $\begin{array}{l}\text { Process of } \\
\text { obtaining } \\
\text { mining } \\
\text { permits }\end{array}$ & .316 & .1945 & -.589 & -.3 & 0.003 \\
\hline Dependent & \multicolumn{5}{|c|}{ Women Participation in ASM } \\
\hline \multicolumn{2}{|l|}{ Adj. R squared } & \multicolumn{4}{|l|}{0.1564} \\
\hline \multicolumn{2}{|l|}{ Std. Error } & \multicolumn{4}{|l|}{2.070} \\
\hline \multicolumn{2}{|c|}{$\mathrm{F}-$ ratio $(3,179)$} & \multicolumn{4}{|l|}{12.25} \\
\hline \multicolumn{2}{|l|}{ Prob. $>\mathrm{F}$} & \multicolumn{4}{|l|}{0.000} \\
\hline
\end{tabular}

Source: Author (2020)

According to the F-statistic (ANOVA test), the model was found statistically significant given the $p$-value of $0.000<0.05$. This means that the results are valid and that a significant relationship exists between the mining legal framework and women participation in ASM in Taita Taveta County. Concerning adjusted R-squared, the results show that the mining legal framework determines women participation in ASM by $11.6 \%$.

Turning to the coefficients, the study indicates that there is a relationship between the mining legal framework and women participation in ASM. This implies that understanding of the legal framework, the ability to meet the requirements and therefore obtain the permit, and the processes involved in meeting the legal requirement of the industry could affect the participation of women in the mining sector. For instance, the study has established a positive and statistically significant relationship between mining permit requirements and women participation in ASM (0.265, Sig.=0.004). The size of the coefficient indicates that unit improvement in the mining legal framework could increase the participation of women in ASM by 26.5 per cent.

According to the results, the process of obtaining mining permits was found to explain women participation in ASM negatively $(-0.589$, Sign. $=0.003)$. In addition, the size of the coefficient indicates that this variable has a great impact on influencing women participation in ASM (58.9 per cent). This means that a decline in the processes of obtaining mining permits could reduce the participation of women in ASM drastically. These results could be attributed to challenges experienced in obtaining permits. Nevertheless, the study has failed to establish a statistically significant relationship between understanding mining laws and women 
participation in ASM. This could be attributed to a poor understanding of mining laws among the respondents.

FGDs have revealed various challenges that women face in acquiring mining permits for their activities. For instance, almost in all FGDs conducted, women have argued that getting permits is very cumbersome and time-consuming. This could explain the reasons why regression findings have indicated a negative coefficient, which implies that the acquisition of a mining permit has an adverse effect on women participation in ASM enterprise. In addition, the study has established that getting those permits is an expensive exercise and they have to pay twice for the same; i.e. both to the National and County government. This, therefore, discourages the majority of women who might want to venture into ASM.

Furthermore, through the FGDs, the study has established that women are often harassed by the authorities in charge of giving out the permits, and also that the administrative offices are located far away from their residential areas. This makes it difficult and even expensive to access mining permits. The other challenge that was brought up by the women during the discussion was the issue of awareness. Some women noted that awareness about the mining permits and the requirements was a big challenge and some of them do not understand the process and, hence, this could lock out any potential entrant. Corruption was another issue that came up during the discussions. Some women stated that they had to bribe some officials for them to get mining permits and that this was a very serious issue to them that requires urgent redress. Furthermore, it became very clear during the discussions that there were no clear guidelines for applying for the mining permits.

The study has shown that the mining legal framework influences women participation in ASM. While mining permit requirements have a positive effect on women participation, the process of obtaining such permits has an adverse impact on women participation. This implies that while women seem to meet the requirements of obtaining mining permits, the process of getting the permits is tedious and complicated and hence, it discourages women participation. This was the first study to ever focus on the legal framework and how it affects women participation. This implies that these findings are very critical to policy formulation to enhance, the role of women in the ASM sector.

\section{Conclusion}

The results reveal that some of the major hindrances to ASM advancements are mainly policy issues. Key among them is the failure by the government to provide engendered policy to enable women participation. However, some of these issues have been addressed in the newly passed Mining Act 2014 although some might have to be handled at the implementation stage. Enhance mining regulations will prevent illicit dealings, reduction of illicit mining, boost revenue collection and ensure better environmental control.

The study concludes that some aspects of the mining legal framework and its implementation are not favourable for women participating in ASM. This is due to the established negative effect. The study has reported that the process of applying for a mining permit is tedious and expensive. In addition, applicants have to pay twice to obtain the permit coupled with corruption on the way. Despite having mining bill 2014, there is a need for vigorous public/ASMs sensitization on the new Mining Bill 2014, legal rights and obligations. Most of the problems in the extractive industry including conflicts are due to ignorance. 


\section{Policy Recommendations}

There is a need for the government and relevant stakeholders to mainstream gender and come up with proper policy frameworks, particularly when it comes to mining licenses This can be achieved by reducing the procedural and paperwork required to obtain work permits. Besides, the government can introduce licenses under different categories where women can easily access medium or small scale mining licenses.

In addition, there is a need to establish a field office of the body offering the ASM mining licenses near the mining area so it can be more comfortable for women to access them. With the growing knowledge of digital technology in Kenya, the government can consider introducing an online license application or giving the necessary resources to county offices to offer licenses to the needy miners.

Policy gaps also exist and there is a need for both levels of government to come up with proper policies and strategies that will improve women's participation in group activities and leadership positions in the community. This will help women share ideas and the problems they face in the ASM industry. The policies and strategies can include coming up with proper health and safety programs that can enable women to bring their children to the worksites. This will allow the women to increase the time spent in the mining activities as they will be able to take care of the children at the same time work in ASM.

\section{References}

Ayuk, E. T., Pedro, A. M., Ekins, P., Gatune, J., Milligan, B., Oberle, B., \& Acquatella, J. (2019). Mineral Resource Governance in the 21st Century: Gearing Extractive Industries Towards Sustainable Development-Summary for Policymakers and Business

Buxton, A. (2013). Responding to the challenge of artisanal and small-scale mining. How can knowledge networks help.?

Fearon, J., \& Dawutey, N. A. E. (2015). Perspectives on Small-scale Mining in the Birim North District of Ghana. Perspectives, 5(16).

Hinton, J., Veiga, M. M., \& Beinhoff, C. (2003). Women and artisanal mining: Gender roles and the road ahead. The socio-economic impacts of artisanal and small-scale mining in developing countries, 149-188.

Hirons, M. (2020). How the Sustainable Development Goals risk undermining efforts to address environmental and social issues in the small-scale mining sector? Environmental Science \& Policy, 114, 321-328.

Intergovernmental Forum on Mining, Minerals, Metals and Sustainable Development (IGF). (2017). Global trends in artisanal and small-scale mining (ASM): A review of key numbers and issues. Intergovernmental Forum on Mining, Minerals, Metals and Sustainable Development, Winnipeg: IISD. Retrieved from

https://www.iisd.org/sites/default/files/publications/igf-asm-global-trends.pdf

International Labour Organization (ILO). (2017). Global Employment Trends for Women 2004. International Labour Office, Geneva.

/http://www.ilo.org/public/english/employment/strat/download/trendsw.pdfS.

KNBS. (2019). Economic Survey. Nairobi: Kenya National Bureau of Statistics (KNBS).

Liu, T., Liu, S., \& Shi, L. (2020). Basic Statistics and Regression Models. In Time Series Analysis Using SAS Enterprise Guide (pp. 15-48). Springer, Singapore.

Maclin, B. J., Kelly, J. T. D., Perks, R., Vinck, P., and Pham, P. (2017). "Moving to the mines: Motivations of men and women for migration to artisanal and small-scale mining sites in Eastern Democratic Republic of the Congo". Resources Policy, 51: 115-122. 
Mkubukeli, Z., and Tengeh, R. (2016). "Prospects and challenges for small-scale mining entrepreneurs in South Africa". Journal of Entrepreneurship and Organization Management, 5(4).

Mishra, P. P., \& Reddy, M. G. (2012). Gender Mainstreaming in Mining: Experiences across Countries. Centre for Economic and Social Studies.

Mugenda, O. M., \& Mugenda, A. G. (2003). Research Methods: Sample size determination. African Centre for Technology Studies.

Mwakumanya, M. A., Maghenda, M., \& Juma, H. (2016). Socio-economic and environmental impact of mining on women in Kasigau mining zone in Taita Taveta County. Journal of Sustainable Mining, 15(4), 197-204.

Rowley, J. (2014). Designing and using research questionnaires. Management Research Review.

Sadan, E. (2004). "Developing a theory of empowerment". Empowerment and Community Planning, 137-168.

Siwale, A., and Siwale, T. (2017). "Has the promise of formalizing artisanal and small-scale mining (ASM) failed? The case of Zambia". Extractive Industries and Society, 4(1): 191201.

Werthmann, K. (2009). "Working in a Boomtown: Female perspectives on goldmining in Burkina Faso". Resources Policy, 34 (1-2): 18-23.

Yakovleva, N. (2007). Perspectives on female participation in artisanal and small-scale mining: A case study of Birim North District of Ghana. Resources Policy, 32(1-2), 29-41.

Zohrabi, M. (2013). Mixed-Method Research: Instruments, Validity, Reliability, and Reporting Findings. Theory \& practice in language studies, 3(2).

Zollo, N. J. (2019). A Study on Artisanal and Small-Scale Gemstones Mining in Taita Taveta County, Kenya (Doctoral dissertation, University of Ghana). 